Within 1-2 km of the larger discordant igneous intrusions the country rocks show a change in both structure and metamorphism from the normal rocks of the migmatite complex. There is a change from amphibolite facies to brown-weathering granulite facies rocks and veins of garnet-hypersthene granite cut lower grade gneisses included in the high grade zone bordering the intrusions. In these border zones the regular structure of the well foliated and banded migmatites which is usual elsewhere, gives way to irregular plastic contortions, often without obvious continuity and with foliation absent or weakly developed. The development of this charnockitic border zone is thought to be closely related to the emplacement of the rocks of the rapakivi suite; however the relationship is complex since the youngest metamorphic effect of the granitic members of the suite commonly results in local downgrading of the surrounding gneisses.

It is tentatively suggested that the varying metamorphic effects of the rapakivi suite may be due to the movement of the water to and from the country rocks at different stages in the crystallisation history of the intrusions.

\title{
PRELIMINARY INVESTIGATIONS IN SOUTH-EAST GREENLAND
}

\section{Bridgwater}

As a first stage in planning a regional mapping programme on the south-east coast of Greenland from Scoresby Sund to Kap Farvel, the available material from previous expeditions has been examined and a provisional geological map is being compiled. A programme of isotopic age determination has been started in collaboration with F. J. Fitch (London University) and J.A. Miller (Cambridge University) in order to help localise areas in which to concentrate future detailed geological mapping. The Geological Survey of Greenland will be very pleased to receive information gathered on recent expeditions to this coast which may be of help in planning and which could prevent a senseless duplication of effort.

The Precambrian rocks from Kap Farvel to Kangerdlugssuaq consist 
mainly of amphibolite facies granitic gneisses with a predominantly steep $\mathrm{E}-\mathrm{W}$ or NE-SW foliation. Large areas of high grade metamorphic rocks have not been noted although charnockites occur on Angmassalik island and on the mainland north-east of Angmassalik. Migmatised relics of metasedimentary rocks are fairly common along the coast; apart from the localities mentioned by Wager (1934) there are also records of limestones on the north coast of Kutsit $\left(60^{\circ} 44^{\prime}\right)$, semipelites at the head of Danells Fjord $\left(60^{\circ} 55^{\prime}\right)$ and a varied series on the south side of Pikiutdleq $\left(64^{\circ} 40^{\prime}\right)$. Metavolcanic rocks, represented by massive amphibolitic and dioritic areas, are fairly common throughout the area.

The age of the original formation of the rocks in the area is unknown. Between Kap Farvel and Tingmiarmiut the gneisses are all thought to have been involved in plutonic activity contemporaneous with the formation of the Ketilidian fold belt in South-West Greenland (circa $1650 \mathrm{~m}$.y.). North of Tingmiarmiut the gneisses contain large metadolerite dykes resembling those of the Ivigtut region and it is tentatively suggested that a pre-Ketilidian basemen occurs in this region. Gabbro-anorthosite lenses, resembling those thought to have been formed by the deformation and metamorphism of the premetamorphic igneous complex of Fiskenæsset (Windley, this report), have been found in the gneisses on the south coast of Pikiutdleq $\left(64^{\circ} 50^{\prime}\right)$.

Ketilidian ages are reported from Angmassalik (Wager and Hamilton 1964) where a late plutonic calc-alkaline suite of rapakivi granites and norites (previously regarded as ?Permian in age) cut earlier amphibolite facies gneisses. These intrusions closely resemble the late piutonic intrusive suite of Kap Farvel described by Bridgwater, Sutton and Watterson in this report. Other calc-alkaline suites of presumably the same age are known from Qutdleq island at the mouth of Anoritô fjord $\left(61^{\circ} 32^{\prime}\right)$ and the head of Lindenows Fjord $\left(60^{\circ} 35^{\prime}\right)$.

The granulite facies gneiss found in the Angmassalik district may represent relics of older rocks; however, the field relationships are uncertain. Wager (1934) describes two periods of amphibolite sheets in this area both of which appear to be later than structures in the host gneisses. Either intrusive phase may mark an important break in the metamorphic history of the gneisses. However the conditions under which these bodies were emplaced is unknown and the present evidence cannot be used to prove tha the gneisses have passed through two mor periods of plutonism.

Between Angmassalik and Nansens Fjord $\left(68^{\circ} 15^{\prime}\right)$, where the Precambrian 
rocks are covered by Tertiary lavas, the gneisses were affected by plutonism at about $1600 \mathrm{~m} . \mathrm{y}$. A single K/Ar age of $2700 \mathrm{~m} . \mathrm{y}$ of a sample which gives a $\mathrm{Rb} / \mathrm{Sr}$ age of $1600 \mathrm{~m} . \mathrm{y}$. may suggest the presence of a partially reactivated basement if only because the age obtained resembles that of the major preKetilidian plutonic activity of the west coast of Greenland (O. Larsen, this report). A similar explanation may account for the discrepancies between $\mathrm{K} / \mathrm{Ar}$ and $\mathrm{Rb} / \mathrm{Sr}$ dates recorded by Kulp et al. (1962 a and b) from the Precambrian gneisses of Gaaseland. In this area the two methods give more normal results with the $\mathrm{K} / \mathrm{Ar}$ age younger than the $\mathrm{Rb} / \mathrm{Sr}$ age from the same specimen.

The basement gneisses are intruded by several dyke swarms. In the area around Angmassalik and further north these are undoubtably mainly Tertiary in age and it is likely that late Phanerozoic dyking persists along the coast south to Kap Farvel where its presence has recently been confirmed. Loose blocks of fresh vesicular lava which have been picked up by Greenlanders in Lindenows Fjord on the east coast and at the head of Tasermiut fjord on the west coast $\left(60^{\circ} 32^{\prime}\right)$ may suggest the presence of young extrusive material under the ice cap much further south than is known at present.

It is reasonable to assume that the Gardar alkali province (1000-1250 m.y.), which is concentrated in an $\mathrm{E}-\mathrm{W}$ fault-controlled zone on the west coast of Greenland, is represented by some of the dykes on the east coast. This supposition is supported by the occurrence of feldspathic dykes and syenite dykes south of Kap Tordenskjold between latitudes $61^{\circ} 10^{\prime}$ and $61^{\circ} 20^{\prime}$, due east of the main Gardar activity.

Little further information can be added to that already known on the Tertiary intrusive centres between Angmassalik and Kangerdlugssuak. Specimens collected by R. B $\phi$ gvad in 1933 suggest that the Kap Gustav Holm intrusion marked by Wager (1934) as gabbro also contains syenites. A mixed gabbro granophyric intrusion from Tasiussaq fjord $\left(66^{\circ} 40^{\prime}\right)$ exhıbits net-veining of the type described from the Scottish Tertiary rocks (Wager and Balley, 1953)

\section{References}

Kulp, J. L. , Kologrivov, R. , Haller, J. and Koch, L. (1962a) Potassium-argon ages on rocks from eastern Greenland. Nature, Lond., Vol.194, 953-955.

Kulp, J. L. Kologrivov, R., Haller, J. and Koch, L. (1962b) Further isotopic age measurements on rocks from north eastern Green and. Nature Lond., Vol. 196, p. 160 only. 
Wager, L. R. (1934) Geological investigations in East Greenland. Part 1. General geology from Angmassalik to Kap Dalton. Medd. Grфnland, Bd. 105, Nr. 2

Wager, L. R. and Bailey, E. B. (1953) Basic magma chilled against acid magma. Nature, Lond., Vol. 172, 68-70.

Wager, L. R. and Hamilton, E. I. (1964) Some radiometric rock ages and the problem of the southward continuation of the East Greenland Caledonian orogeny. Nature, Lond., Vol. 204, 1079-1080.

\section{K/Ar AGE DETERMINATIONS FROM WESTERN GREENLAND}

\section{Ole Larsen}

(mass spectrometry in collaboration with Jørgen M $\varnothing l l e r$, Fysıske Laboratorium II H.C. Ørsteds Institut, København)

A programme of $\mathrm{K} / \mathrm{Ar}$ age determinations on the rocks of western Greenland from Upernavik $\left(72^{\circ} 50^{\prime} \mathrm{N}\right)$ to Kap Farvel $\left(59^{\circ} 40^{\prime} \mathrm{N}\right)$ has been started and the first results are presented below. The samples used in this first group of resul:s have been selected so that the date obtained would represent the most significant geological event in each area and $\mathrm{s}$ mples from areas in which the geological history is known to be highly complex have been avoided wherever possible. The geological interpretation of the results has been the responsibility of the individual geologists who supplied the samples while the overall geological history outlined in this compilation is that current among members of the Geological Survey of Greenland.

The firs 29 results obtained are listed below together with comments on the geological significance of each date. The figures given re based on preliminary calculations and may be subject to slight ammendments when a full report is published on the work. The error has not yet bcen calculated for most of the determinations; it is assumed to be $\pm 1-3 \%$ unless otherwise noted. 